\title{
BANKING'S OPPORTUNITY TO SERVICE THE SMALL LOAN NEEDS OF THE PUBLIC
}

\author{
Cart K. Dellmuth* \\ EARLY HISTORY
}

Any comment on present day opportunities for American banks in the small loan field might well be preceded by a sketchy review of pertinent historical events which have led us to this mid-way point in the twentieth century.

Bank credit, in the modern sense, came into being in the twelfth century with the founding of the Bank of Venice, commonly referred to as the first public bank. Until the fifteenth century this bank and others in Italy catered almost exclusively to the wealthy class. To correct this condition the Franciscans helped create nonprofit organizations to lend money to individuals of modest means. Since little, if any, interest was charged, those organizations were operated on a charitable basis and as such many failed. However, these early experiences invited-and later established-the belief that a lender should receive compensation for service rendered and risk involved and a suitable charge was thereafter deemed legal and proper.

Until the seventeenth century in Italy, the financing needs of the populace were only helped through the influence of the church, whereas in England laws designed to give relief from exorbitant rates were enforced by the reigning sovereigns. Thus the Bank of England, established in I694, subsequently became the bank for England and its colonies, and today is one of the leading financial institutions of the world.

When the English colonists settled in America they brought many of the economic ideas of their native country and as early as the beginning of the nineteenth century it is recorded that several New York houses adopted the instalment system for furniture sales. The most rapid advances in this type of financing, however, have taken place in the last quarter century.

\section{EXPANSION}

The advent of the automobile is a milestone worthy of note. At first, sold on a cash basis and with production and distribution moderate, it was strictly a luxury item. Manufacturers realizing the enormous potential if their product could be in-

\footnotetext{
- Graduate of Swarthmore Colicge (Pa.) with a degree in economics. After seven years in business Mr. Dellmuth returned to Swarthmore and served in an administrative capacity and as a member of the faculty from 1938 to 1949 . In 1949 he became the first full-time Secretary of the Pennsylvania Bankers Association, the largest state bankers association in America. During his incumbency the PBA greatly expanded its activities in the broad fields of education, legislation, and public relations. Likewise, he is a member of the Research Council of The American Bankers Association, and a member of the Board of Trustees of the Pennsylvania Bankers Association's Educational Foundation, and the author of "Think It Over," an illustrated booklet which outlines the forces bearing down on the independent character of our banking system. On July I, 1953, Mr. Dellmuth became Vice President of the FidelityPhiladelphia Trust Company.
} 
troduced and sold to the masses appealed first to the bankers-and then to private sources-for help with their needs. It was private financing of automobile purchases which prevailed for a period of years and so continued until after the end of World War I, when in I9rg, the General Motors Acceptance Corporation was organized primarily as a financing outlet for that company's products. GMAC was highly successful and resulted in many other corporations forming their own finance outlets in various parts of the country.

In this period of expansion the finance companies borrowed considerable sums from the banks in addition to providing their permanent capital, so that even in those days the banks were indirectly the source of a large fraction of the credit extended to automobile purchasers.

In $x 926$ the Economic Policy Commission of The American Bankers Association engaged Milan V. Aynes, an economist, to make a study of instalment selling and its financing. A report on this study, which extended over a period of four months, was made to the Executive Council of The American Bankers Association on May 4, I926. At the time, the ABA felt that direct instalment financing was a function beyond their scope. They pointed to the fact that many of the old line bankers were completely opposed to the idea of mass financing of commodities and felt it should remain in the hands of finance companies who were specializing in that type of business. As a result the finance companies in their dual role of financing both manufacturers and distributors reaped the whirlwind alone. In I926 a few banks with the pioneer spirit had entered the field on an indirect basis, but still little heart was being shown for further development of the direct process.

Between I922 and 1929 the banks had no problem lending money to commercial borrowers. However after 1929, a sharp decline in commercial borrowing presented the alternatives of establishing new outlets for putting deposits to work, or of investing them in low yield government bonds. In other words, deposits had to be leased in order to produce earnings, or risk the maintenance of large uninvested deposits which in turn would invite sharp criticism from shareholders because of reduced dividend returns.

With the exception of the Morris Plan institutions and other industrial banks, the personal loan or consumer credit field remained comparatively dormant in commercial banking circles until the late twenties.

\section{Genesis of Commercial Bank Instalment Lending}

In I928, the following significant editorial appeared in a newspaper in Fairmount, West Virginia:

It is among the possibilities that the most important item in last night's paper set forth the simple fact that The National City Bank, one of the great financial institutions of the world, has decided to make loans to people on salary. The Bank may be relied upon to apply an abundance of scientific spirit to the problem and the likely outcome is new principles and new methods which when followed by other banks will open up as well as provide funds cheaply for people in need. 
The Fairmount editor was indeed something of a prophet. But let Mr. J. Andrew Painter, Vice President of The National City Bank, describe the happenings as he outlined them in an address on October 16, 1952.

The Personal Credit Department debut on May 4, 1928 was an exciting occasion. The staff of only four people in the basement at the corner of $42 n$ i Street and Madison Avenue was literally besieged by loan applicants. Newspapers reported the opening extensively. The Daily News, for instance, said in part:

"The managers of deparment stores' bargain basements might have flushed green with envy yesterday had they been on hand to see the crowd that surged in. For The National City Bank has now established a personal loan department where Mr. Everyman may borrow and be sure he will not be gypped by loan sharks. The minute the doors were opened the crowd surged in. Apparently everyone went away happy in the prospect of paying debts or buying some needed things."

A flood of publicity followed that first day. Prominent public figures commented on the innovation of a big bank inviting the financial humble to come in and borrow. Editorials and cartoons (one by the famous Rollin Kirby) praised the blow dealt loan sharks, and the department went on to make bank loan history in the tremendous volume of business it did.

Let me recite a few additional facts which Mr. Painter did not include in his remarks. The National City Bank from that humble start on May 4, xg28, until November of 1949, extended credit to 4,400,000 customers for a total of $\$ 1,425,000,000$. At the end of 1952 their balance of instalment loans outstanding amounted to approximately $\$ 240,000,000$ spread over 600,000 customers. The four pioneers in that business have grown to a staff of I200 people, occupying seven floors of their Madison Avenue building. You ask about loss ratio, the dreadful spectre which haunted the old line banker. Suppose we return to Mr. Painter again, this time to quote some lines from an address delivered to the Michigan Bankers Association in November, I949:

Our loss records go back to 1928 , the year we started. I929 our first calendar year being a boom year produced a sizable volume and outstanding today are $46 /$ Iooths of $x \%$. Nevertheless in 1933 and 1934 both depression years we made loans approximating the 1929 dollar volume and in number considerably larger. Outstanding of those years today are about $x / 20$ th of $x \%$ and $x / 25$ th of $x \%$ respectively. While our own credit policies, adjusted to $1933-34$ conditions, were partly responsible, this record also can be attributed to the innate good sense of the borrowers themselves. At no time did we "clamp down." We maintained the even tenor of our policy always to respond to repayable calls for "help needed."

This interesting performance can be applied in principle to many other banks throughout the country, demonstrating not only the willingness, but the ability over a period of many years of the average borrower to maintain a creditable reputation for repayment. Since 1928 banks by the thousands wisely have decided not to restrict themselves to wholesale credit to finance companies and loan companies, but to lend directly through the now popular medium of personal loans. 
Thus the opportunity which had existed for so long has been belatedly realized and American banking is now adequately servicing this basic credit need for the public. Furthermore, the aloofness usually associated with banks has gradually disappeared with the entry of more banks into the field of instalment financing. Most banks are in effect now saying, "we are merchandisers of money just as your department store is a merchandiser of goods; why not give us the chance to serve you?"

\section{A Formula}

What then should the average bank do to make the most of its opportunities in the field of instalment lending? W. Harold Brenton, President of The American Bankers Association and President of the State Bank of Des Moines, Iowa, addressing the National Instalment Credit Conference in Chicago, March, I952, answers in part as follows:

In order to take advantage of the opportunity given to bankers, I want to enumerate several of the things they should consider.

I. Personnel Training. Every good instalment credit staff I have even seen has been well trained in lending and operational functions, but many of them fall way short in their understanding of human relations. Many need careful training in the human aspects of dealing with people.

2. Friendliness. The thing that counts most is the warmth of friendliness. The nature of the banking business has a tendency to develop austerity. This is something every bank officer should understand and constantly strive to remedy. The general atmosphere of a banking institution can be set by the selection and training of employees. Friendliness is important all over a bank, but at no place is it more necessary than in the instalment loan department. It is there that most customers get one of their first glimpses of their bank, one of their first feelings for their bank, and one of their first acquaintances with their banker. There a man-from-the-street learns that bankers are human, kindly, friendly, and interested in them.

3. Separate Quarters. Most banks start instalment lending through regular lending offcers or in a small department in a corner of the bank's lobby space. Those small beginnings have been good as a first step in learning the business and in training personnel. The next step is usually consideration of whether to remain in small quarters or to expand. Expansion requires a larger staff with more expense. The real question in considering expansion in the instalment credit field is whether or not the bank wants to put forth the effort and expense to attract more people to the bank. Once there is the desire to develop more friends, the ways and means of accomplishing it can be worked out. It is always a surprise to me how rapidly instalment loan departments grow when placed in separate quarters. People are attracted to any new development; and when that new development affects them personally, it has immediate appeal. Separate quarters provide them with specialized, personal attention.

4. Hours. Here is another feature which attracts business-the instalment loan department usually keeps open longer hours than the regular banking hours. This matter of business hours has much drawing power. Many people have working hours that conflict with the usual banking hours. Small loan companies have long understood this and so have been able to attract many customers at higher rates by remaining open at hours convenient to the public.

5. Overcoming the Public's Timidity toward Banks. I always wonder why so many 
people are timid about entering a bank. Surveys reveal that many people just do not feel at home and comfortable in a bank. It may be for the reason that a man hesitates to enter the women's department in a large store. Department stores understand this timidity and are remedying the situation by establishing women's wear departments for men only, complete with models. The banks have a great opportunity to overcome this hesitancy by offering a more personalized, friendly service in their separate consumer credit departments.

6. Increases General Banking Business. A growing instalment loan department can furnish a natural entry for a large volume of general banking business. Here is a fact and an end result not to be overlooked. At the same time that a separate instalment loan department is attracting men and women, the general banking personnel must be alert to building an acquaintance among the same people.

7. Helping People with Their Problems. Most people have financial problems which are often terrifying to them. Those problems may not seem large to the banker, but they are huge to the man who has them. Most of those people have no other reliable place where they can go for advice. The general staff of a bank can fill an unusually important place in a community by offering this personal service.

What would you think of a bank announcing to the public that its officers on a certain half-day a week would donate their time to helping people with their personal financial problems-with no thought of remuneration-customers and non-customers alike? It would be an interesting study in. human relations. It could be a fine investment in building still greater confidence in banking.

\section{Banking's Participation to Date}

A review of the foregoing begs the question of what American banking has contributed to date in the field of instalment financing. Perhaps the answer can best be arrived at by using the following figures listed by the Federal Reserve authorities (March 3I, I953) as a background:

$$
\begin{aligned}
& \text { Type of Credit } \\
& \text { Automobile Paper................. \$ 8,783,000,000 } \\
& \text { Other Consumer Goods Paper.......... 5, 562,000,000 } \\
& \text { Modernization Loans................ I, } 1384,000,000 \\
& \text { Personal Loans.................. 3,956,000,000 } \\
& \$ \frac{3,96,28,000,000}{\$ 19}
\end{aligned}
$$

Significant is the fact that $\$ 8,086,000,000$ or 42 per cent of this $191 / 4$ billion dollar total of instalment credit outstanding was held by the commercial banks. Remembering that direct bank participation in this type of lending has been building up for only the past twenty-five years, one might be excused for concluding that the country's banking industry has already established itself as a major factor in the field of instalment credit.

\section{The Future}

Banking's future opportunities in the small loans field seem increasingly alluring. With 7000 banks now maintaining separate instalment loans departments and an estimated total of 12,000 banks doing some degree of instalment financing, one might suppose that banks will be looked to more than ever to service the small loan needs of the public. 